\title{
Comparative Financial Analysis Of The Mexican Rural Sector
}

Flory Anette Dieck-Assad, ITESM, Mexico

\begin{abstract}
The development of the Mexican rural sector is vital because it is the source of raw materials needed for production in the manufacturing sector. Thus, it is indeed important that its development follow that of the industrial sector. The main objective of the present research is to evaluate the growth of the rural sector during the presidential term of Felipe Calderon (20072012) and to discover the lights and shadows that revolve around this suffering sector of the Mexican economy. The analyzed statistical evidence shows an important lag and stagnation of the development of the rural sector since 1960 in Mexico. Additionally, a decrease in the contributions of the rural sector to the entire economic development in Mexico in 2012, compared to the one registered 33 years ago (in 1979), is considered. The statistical evidence supports the conclusion that the Mexican rural sector has not been able to show any progress, regardless of the noble governmental initiatives and efforts. Financial government resources should not only be directed to pay salaries and subsidies, but through a more effective leadership, the agricultural government agencies could try to increase investment in infrastructure, development, and application of new technologies set in the context of civic responsibility, ethics, and a sustainable development approach.
\end{abstract}

Keywords: Mexican Rural Sector; Financial Resources for the Rural Sector; Secretary of Agriculture

\section{INTRODUCTION}

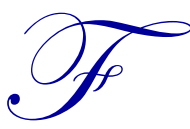

or a world characterized by the excitement of urban life and the emergence of so many technological advances, it seems that talking about the rural sector could be a boring or monotonous theme in a conversation. It sounds more appealing to discuss scientific breakthroughs or popular social networks than talk about the rural sector - an issue that is unheard of; therefore, there are few things to say about it because it is only interesting for people who live, suffer, and struggle to survive in the Mexican countryside.

The heartbreaking silence of the rural sector in Mexico is undoubtedly facing the indifference of city dwellers, among other sectors that can add up to promote this neglect of the rural sector. However, the activity generated in this sector is extremely important for the economic activity and the sustainable development of any country, just as researcher Ugo Pipitone asserts: "None of the considered developed nations have managed to achieve economic and social welfare of its population without including the rural sector. The future of our country is closely linked to the inclusion of the rural sector and its inhabitants in any social project that is intended to be pursued" (Reynoso, 2001a).

According to Reynoso (2001a), the rural sector, in market terms, is one of the most hurt sectors by the crisis and has been banned from the country's economic development model, which is very serious if we consider that the rural sector is one of the pillars that supports the economic structure of any country.

When examining the diagnoses that have been made regarding the sector in recent years, information and statistics show a bleak picture; economic and life quality indicators show that, in many aspects, the rural sector and its inhabitants not only have been deteriorated, but have also backtracked, leaving farmers in poverty conditions comparable to those countries with smaller economies than Mexico. The development of the Mexican rural sector is crucial because that is where all the necessary raw materials are generated and obtained for the production of any 
manufactured good in Mexico. Therefore, it is necessary that its development shows equal progress as that of the industrial sector.

Mexico has an advantage, due to its great geological diversity, of having many types of climates and soils, placing the country in a privileged place for the wide variety of raw materials that can be obtained from the crops. However, the wasted time undergone by the rural sector by not receiving the attention it requires has caused its growth not to be optimal. It could even be considered a hindrance to economic growth by generating more problems than benefits due to its productive inefficiency.

The objective of the following research is to evaluate the performance of the rural sector during the administration of President Felipe Calderon and discover the highlights and the shadows that characterize this beaten sector of the Mexican economy. This analysis seeks to be a continuation of the research proposed by Dieck \& Peralta (2013) where the reasons for the macroeconomic stagnation of productivity of the Mexican economy were analyzed since 1979 - a paralysis that has also characterized the rural sector. The proposed hypothesis of this paper is an extension of the results of the aforementioned research but now applied to the rural sector with a financial, productive, and ethical approach.

\section{LITERATURE REVIEW}

In Mexico, as in any other nation, the rural sector is the basis of economic development. Proof of this is the fact that in the early twentieth century, a high percentage of the population lived in rural areas. This percentage of the population remained there until the 1940s; thereafter came the rise of industrialization, which was present until the mid-1960s. In particular, during this phase, the strong performance of the rural sector promoted the expansion of the domestic market, supported the country's food self-sufficiency, encouraged agricultural exports, and contributed to urban growth, generating a steady flow of workers from the rural areas to cities and industrial zones (Escalante et al., 2005). Formally, that span of time was known as the "Mexican Miracle" because there was a rapid growth of economic productivity. All this happened under an economic protectionism policy - everything needed for production was obtained from the Mexican rural sector and, when used in Mexican industries, it caused a virtuous circle of mutual support between both the rural and industrial sectors.

But times change and as an inevitable result, globalization came along, with both its lights and shadows. Several treaties were negotiated with foreign countries in order to promote worldwide productivity and efficiency. Mexico's openness to international markets also brought technological advances and know-how as well as a variety of international products that could be easily obtained from abroad at a very good price.

As stated by Reynoso (2011a), when examining the diagnoses that have been made regarding the sector in recent years, information and statistics show a bleak picture; economic and life quality indicators show that, in many aspects, the rural sector and its inhabitants not only have been deteriorated, but have also backtracked, leaving farmers in poverty conditions comparable to those countries with smaller economies. Unfortunately, this neglect has resulted in a lower quality of life and a reduction in growth opportunities for the families living in the Mexican rural sector.

As shown by Escalante et al. (2005), Figure 1 compares the behavior of total GDP (Gross Domestic Product) with the performance of the rural GDP from 1960 to 2002 in millions of 1993 Mexican pesos.

This sample can be divided into three periods:

1. 1960 to 1978 is where total and rural GDP showed positive growth rates.

2. 1979 to 1989 was a period of stagnation due to the reduction of government support and trade liberalization.

3. 1990 to 2002 showed greater volatility and lower growth rates compared with those recorded in the 60's.

As of the year 1979, this change in trend was also identified by Dieck \& Peralta (2013) - for macroeconomic labor productivity (GDP per remunerated labor) - who identified the macroeconomic events that 
may have influenced this trend - the Mexican peso devaluation and the increase in energy prices. They also emphasized that the low productivity of a country is linked to a decrease in the life quality of its inhabitants.

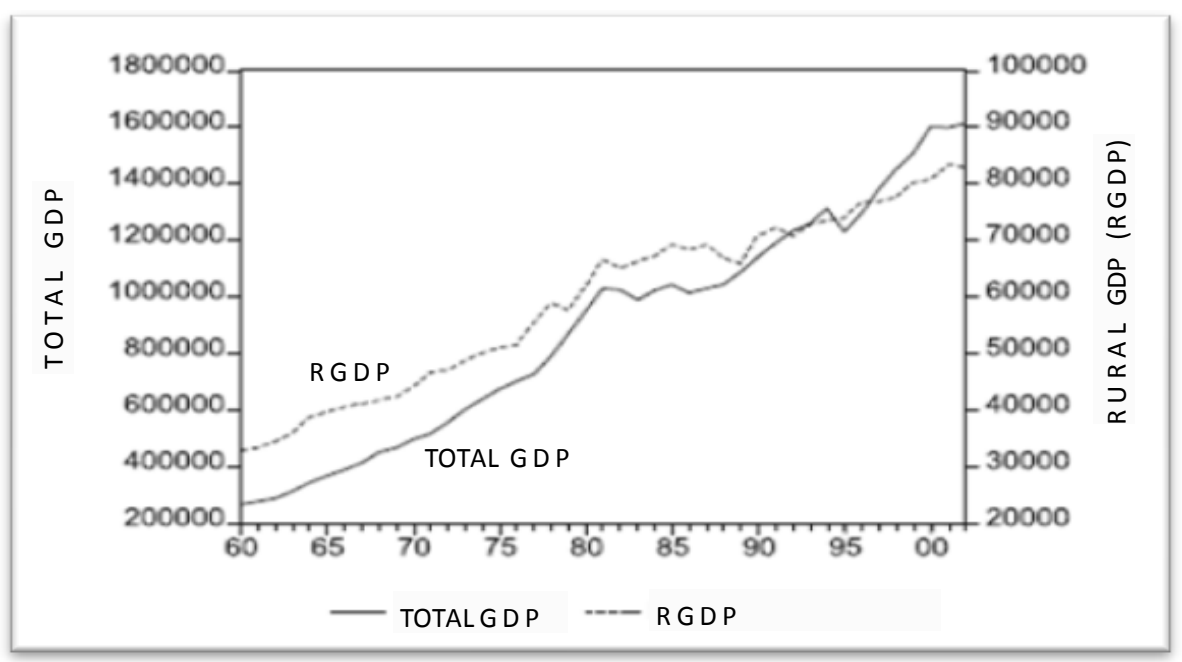

Figure 1: Comparison of Total and Rural Gross Domestic Product (GDP) 1960-2002 (Millions of 1993 Mexican pesos) Source: Escalante, R., Galindo, L. M., \& Catalan, H. (2005)

\section{HYPOTHESIS}

On September 2012, the Secretary of Agriculture pointed out that the budget of the Special Concurrent Program for the rural sector during the administration of President Felipe Calderon was $60 \%$ higher than that of President Vicente Fox, increasing from 1,015,286 million Mexican pesos in the period 2001-2006 to 1,624,029 million Mexican pesos from 2007 to 2012 (Bosque, 2012). Despite the economic importance that Felipe Calderon gave to this key sector of the economy, the hypothesis proposed in this paper is that these financial resources were not effectively channeled in order to bring this sector out of its historical stagnation.

There could be a theory that the unexpected weather events that occurred during President Felipe Calderon's administration (2007-2012), such as droughts and floods, might explain the ineffectiveness of the allocation of financial resources to the Mexican rural sector, but this is not the case. This paper proposes a discussion and analysis of the possibility that the investment channeled to the rural sector was not directed toward investment in infrastructure nor used for the application of new technologies to crops, in addition to the inadequate structuring of farm subsidies, which have not been sufficient to bring the Mexican countryside out of its historical stagnation.

This research becomes a call for those responsible of designing the agricultural policy in Mexico. This paper intends to promote a healthy debate that could identify the reasons why poverty increased in the rural sector by 15\% during the six-year term of President Felipe Calderon, despite the fact that he directed more financial resources to the rural sector. Could it be that the tools and the designed financial strategies were not enough to take advantage of this important financial contribution from the government to the rural sector?

The hypothesis of this study is similar to that tested by Dieck \& Peralta (2013) where it was shown that macroeconomic labor productivity in Mexico grew rapidly until 1979 due to the parallel growth of capital investment, the use of energy, and technological improvements. After 1979, there was a virtual stagnation in economic growth due to a slowdown on investment and the global economic impact caused by the constant increases in energy prices. Presumably, this also occurred in the agricultural sector.

The objective of this research is to evaluate the growth of the Mexican rural sector during the most recent years, as discussed in the following sections, and identify whether the last administration (Felipe Calderon from 
2007 to 2012) was effective in restoring the rural sector dynamism and vigor it desperately needs to become the basis for Mexico's sustainable development.

\section{TREND ANALYSIS}

Despite all the efforts made to support the rural sector, the XXI century began in 2000 with a rural GDP growth below the growth rate of total GDP, causing a detriment of the levels of life and well-being of the Mexican rural sector. Banco de Mexico (2012) reports that while total GDP grew 13.45\% in 2006, compared with that recorded in year 2000, the rural GDP grew at a lower rate of $12.66 \%$ for the same period.

Meanwhile, total GDP grew at $4.36 \%$ in 2011 compared with year 2007 (when President Felipe Calderon began his administration), while rural GDP declined, registering a negative growth rate of $-2.20 \%$. The most recent data reported by the INEGI (2011) indicate that the average annual growth of the rural sector was only $0.4 \%$ between the beginning of Calderon's term (2007) and the first half of year 2012 (Bosque, 2012).

Figure 2 shows the growth trend in the rural sector which still maintains a lower growth rate compared with total GDP. This is certainly a prolongation of the scenario identified in Figure 1 by Escalante, et al., (2005). Figure 2 identifies a virtual stagnation of the rural sector from year 2006 to 2011.

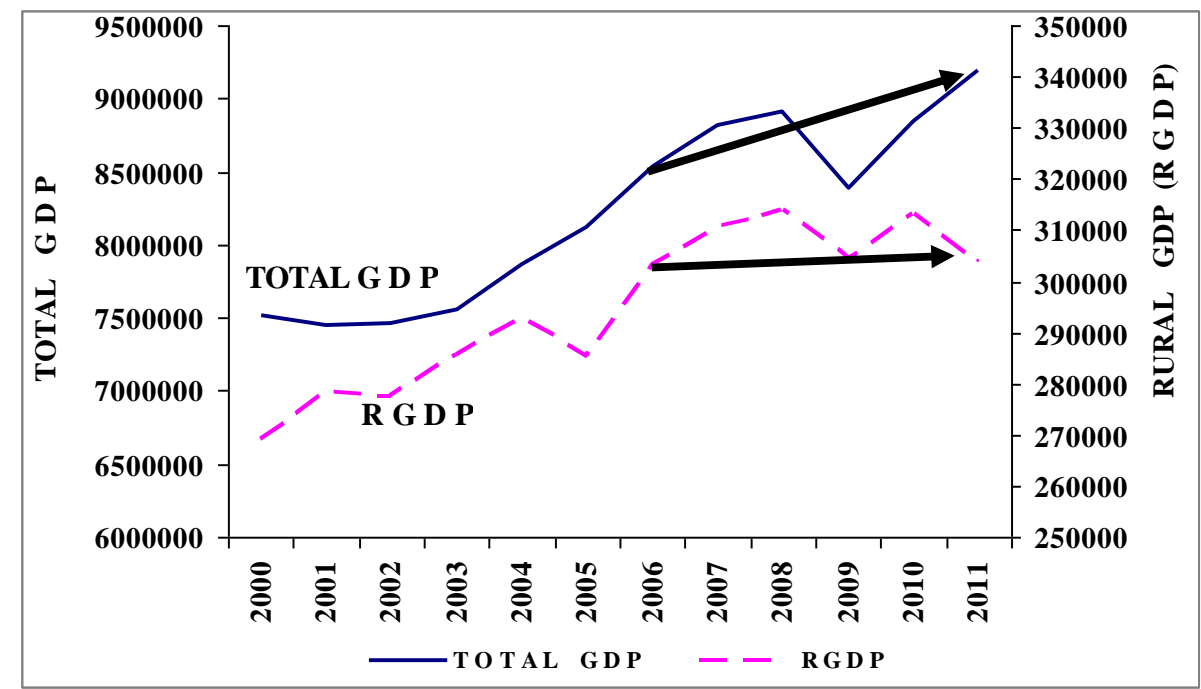

Figure 2: Comparison of Total and Rural Gross Domestic Product (GDP) 2003-2011 (Millions of 2003 Mexican pesos) Source: Calculated with data from Banco de Mexico (2012).

Table 1 shows that the rural GDP follows a less dynamic historical growth trend compared to total GDP an inherited behavior from previous years.

Table 1: Comparative Annual Growth Rates of Total and Rural GDP \%

\begin{tabular}{|c|c|c|}
\hline \multicolumn{1}{|c|}{ Year } & Total GDP & Rural GDP \\
\hline $2008 / 2007$ & 1.19 & 1.23 \\
\hline $2009 / 2008$ & -5.95 & -3.16 \\
\hline $2010 / 2009$ & 5.53 & 2.90 \\
\hline $2011 / 2010$ & 3.91 & -3.04 \\
\hline
\end{tabular}

Source: Calculated with data from Banco de Mexico (2012).

Table 2 also shows the continuation of the inherited historical trend in the rural sector with a continued decline in its contribution to total GDP. As noted, the contribution of the Mexican Rural sector to total GDP declined during Calderon's term - from 3.5\% in 2007 to an estimated 3.3\% in 2012. This is a key indicator that shows that there was really no breakthrough in the rural sector as a result of the various public projects implemented to help trigger its growth. 
Table 2: Participation of Rural GDP in the Total GDP (2000-2011)

\begin{tabular}{|l|c|c|}
\hline \multicolumn{1}{|c|}{ Year } & Presidential Term & Percentage (\%) \\
\hline 1965 & & 8.8 \\
\hline 1970 & & 7.9 \\
\hline 1975 & & 6.5 \\
\hline 1980 & & 6.6 \\
\hline 1985 & & 6.2 \\
\hline 1990 & & 6.0 \\
\hline 1995 & Felipe Calderon & 3.6 \\
\hline 2000 & & 3.6 \\
\hline 2006 & & 3.5 \\
\hline 2007 & & 3.5 \\
\hline 2008 & & 3.6 \\
\hline 20109 & & 3.5 \\
\hline 2011 & & 3.3 \\
\hline $2012 *$ & & 3.3 \\
\hline
\end{tabular}

* January - June 2012. Source: Calculated with data from Escalante et al. (2005), CEPAL (2011), and Banco de Mexico (2012).

At a macroeconomic level, the contribution of rural to total GDP has dramatically declined in recent years, even though some segments and products of the sector have improved and rendered positive results, particularly those related to the large agri-businesses.

The lag that is still alive in the rural sector cannot be considered to be the fault of President Felipe Calderon, who took every effort to direct more financial resources to the rural sector. What can be seen is that the lower share of the rural sector in the growth of the national economy continues its downward trend that began in the 60s and has worsened in recent years. The Mexican rural sector is still carrying the stigma of a historical lag that has not been able to correct its path. The challenge is to identify the structural obstacles in the Mexican rural sector which have prevented it from recovering from the curse of underdevelopment where it has been weighed down for 33 years (1979-2012).

As shown in the previous table, there has actually been a decrease in the rural sector's contribution to total GDP, which is a proof that none of the desired progress has been made.

Given that the progress in the agricultural activity has not been able to recover since the 60 's, this issue has been kept alive in the National Development Plans of Mexico as an important, but yet unachievable, objective to date. The National Development Plan, designed by President Felipe Calderon for the period 2007-2012, recognized that there was some progress in the period from 2000-2006, where the rural GDP grew at an annual rate of $2.4 \%$ and recorded a decrease in its deficit balance in 2006 , from $60.9 \%$ to $15.3 \%$. However, this diagnosis also emphasized that the rural sector is the one with the lowest productivity, being only one-quarter of the contribution of the industrial sector and less than one-fifth of the participation of the services sector (PND, 2007). This same plan also highlights the deterioration suffered by the rural sector, making its progress even more difficult. According to the 2007-2012 National Development Plan, 67.7\% of the land with productive potential has some degree of degradation (chemical, wind, water, or physical). This loss of workable resources implies the provision of fewer jobs, lower incomes, and a consequent decline in living standards, making it precarious and causing a decrease in social welfare.

\section{FINANCIAL SUPPORT TO THE RURAL SECTOR}

During the 1980s, several projects emerged to support the Mexican rural sector. One of them was the creation of a shared risk trust - Fideicomiso de Riesgo Compartido (FIRCO for its initials in Spanish) in 1984 by the Mexican Secretary of Agriculture, Livestock, Rural Development, Fisheries and Food (SAGARPA in Spanish). Its main objective is channeling public, private, or mixed resources to solve the financial scarcity of investors who have limited access to venture capital or credit required for entrepreneurship and the success of their projects (FIRCO, 2012). However, this strategy did not guarantee an immediate recovery of the rural sector in Mexico. 
The mismanagement of government resources allocated to the rural sector is one of the greatest obstacles for Mexican rural progress. Bosque (2012) indicates that despite all the support and fresh resources directed to the rural sector, its lag persists due to a limited investment in infrastructure and the development and application of new technologies, among other things, while most of the resources go to subsidies and salaries. According to Manuel Molano, a specialist in the Mexican Institute for Competitiveness, subsidies, social programs, and current expenditures account for most of the rural sector budget, while the programs aimed at productivity, technological development, and infrastructure are the last priority (Bosque, 2012). This paves the way to infer that the rural sector will continue to be a financial burden for the federal government.

The idea of creating specialized rural government agencies is to segregate roles of specialists in the field who could achieve a fair and custom-made distribution of resources to promote development and progress in the rural sector. However, apparently there is still a missing ingredient needed to rescue the rural sector from its historical lag from that curse that has plunged it into oblivion and poverty.

The government's intention of creating several public programs to support the Mexican rural sector, such as PROCAMPO and ASERCA (Support Services for Agricultural Marketing), is considered commendable because it shows an interest for this important sector of the economy to stand out, again become a source of wealth, and achieve its place alongside the industrial sector in terms of its share to GDP. The creation of legislation for this sector, such as the Sustainable Rural Development Act, allows for a legal framework to regulate and guarantee agricultural development. According to Ardila (2006), this law seeks to promote social and economic welfare of rural population through diversified sources of employment - including non-agricultural - and providing services to highly lagged regions. However, the enactment of more laws will not guarantee success if they are not strongly applied in practice to generate the intended change.

Furthermore, the government's financial programs were designed to create rural jobs and to launch longterm sustainable projects. However, these programs were not just created for the sake of helping philanthropically. Since capital is being invested, regardless if it is private or public, these rural government financial programs have a lucrative attribute; thus, the profitability of the project is required in order to obtain government financial aid.

There has been a gradual loss of agricultural areas with productive potential (see Table 3). At the macroeconomic level, the ability to generate foreign income from the rural sector has decreased because of the decline in the productive area specialized in production for export crops. The productive area of land for domestic consumption crops (rice, oats, barley, beans, corn, sorghum, and wheat) has decreased causing an increase in poverty. The non-traditional crop areas grew due to privileged farmers who have the knowledge, experience, and the sufficient resources to care for their land in order to become productive. They are probably the ones who greatly contribute to total rural productivity and even find it easier to get government financial aid because they have more information and resources at their disposal. This leaves scarce opportunities for the small producers to qualify as recipients of such financial support because large projects are more profitable and more attractive for capital investment than small projects.

Table 3: Potentially Productive Area in the Mexican Rural Sector 2000-2010 (thousands of hectares)

\begin{tabular}{|l|c|c|c|}
\hline Year & a) Domestic Crop Consumption & b) Traditional Exporting Crops & c) Non Traditional Crops \\
\hline 2000 & 11,638 & 3,639 & 3,457 \\
\hline 2001 & 12,572 & 3,803 & 3,658 \\
\hline 2002 & 11,924 & 3,246 & 4,146 \\
\hline 2003 & 12,473 & 3,279 & 4,367 \\
\hline 2004 & 12,179 & 3,387 & 4,626 \\
\hline 2005 & 10,541 & 3,368 & 4,620 \\
\hline 2006 & 11,727 & 3,401 & 4,839 \\
\hline 2007 & 11,719 & 3,430 & 4,905 \\
\hline 2008 & 11,982 & 3,412 & 5,109 \\
\hline 2009 & 7,789 & 3,401 & 7,499 \\
\hline 2010 & 9,153 & 3,404 & 7,611 \\
\hline
\end{tabular}

a) rice, oats, barley, beans, corn, sorghum, and wheat. b) fruit, vegetables, and industrial. c) fodder, tubers, oilseeds, organic, ornamental, seeds. Source: Calculated with data from CEPAL (2011). 
People with smaller-scale proposals are those who have the agricultural activity as their main source of income. Their lack of education does not allow them to get jobs outside their own farms. Thus, it is crucial and vital for them to get on with their rural jobs. They are so committed to their business that they even forego academic preparation and also incorporate the members of their family to work the land, no matter how old they are.

By evaluating the actual conditions of the rural sector, productively worn out and wasted, one can understand the decreased welfare of its owners, causing the abandonment of the rural areas because of scarce labor opportunities and the income needed to subsist. The effort to relieve the precariousness of the living conditions in the rural sector because of the failure to receive the needed income became the seventh objective of the 2007-2012 National Development Plan which seeks to increase the human development and patrimonial standards of Mexicans living in rural areas (PND, 2007). The purpose of the Plan is to diminish poverty so that the rural inhabitants could have the means and sufficient resources to work their land and increase agricultural productivity. Another objective within this Plan is to supply the domestic market with healthy, high-quality, and affordable foods coming from Mexican crops.

As previously mentioned, the opening to foreign trade brought both benefits and shadows, where the rural sector suffered the most. Now the government seeks to revive the self-sufficiency of the rural sector and encourage agricultural production and productivity. These are excellent ideas and goals that demonstrate good intentions. However, the mechanisms and instruments designed to achieve these objectives must be reassessed because the statistical evidence shows that the rural sector decay has not been reverted and is still dragging problems from the past. According to Reynoso (2011b), at the end of the XX century, the rural sector is dragging old problems while facing the challenge of globalization, which involves the expansion of economic, cultural, and information spaces, where national borders become relative and new forms of producing, consuming, trading, communicating, and work organizing are some of the important changes for farming families that represent complex phenomena and unprecedented situations. The lag of the rural sector has been growing like a snowball due to its lengthy stagnation of over 33 years (1979-2012), which has been accumulating problems through the course of time.

As analyzed earlier, the mismanagement in the government allocation of resources to the rural sector is one of the main obstacles for Mexican agricultural progress. Therefore, what needs to be done simultaneously is to direct more resources to the rural sector and to specifically identify the 'how' and 'where' these resources are taken to effectively revitalize the Mexican rural sector. There is no doubt of the promotion of the Mexican rural sector during Calderon's term since the rural population is well aware of the government financial programs and the mechanisms to obtain resources for both social assistance and rural development activity. The problem is the lack of financial culture and guidance in managing that aid; so, at the end, it seemed as if they did not receive any financial support.

A simple example was identified when interviewing several farmers (Reynoso, 2011b) who said they were given money to buy seeds, but they all bought the same seed for planting garlic. The consequence of this was that the crops were not diversified, causing a negative impact on their income; having a higher supply of the same product decreased its price and their income. The increased competition among them to sell their product at a very low price affected each other in the profitability of their projects, failing to recover the initial investment.

These farmers also commented that there is a lack of knowledge of what crops to promote and they are accustomed to wait for others to help. Since the government is the only one that supports them, there is a lack of initiative for rural people to excel on their own. So, if they do not receive support from others, they do nothing to resolve their situation, which further aggravates the stagnation observed in the rural sector.

This reveals the need to design counseling and opportunity identification policies to support the rural sector. The support has to be directed toward identifying the needs of the rural sector, their opportunities for improvement, and to help them become leaders in their own communities. They need counseling in improvements needed in infrastructure, technological development, and in the deep knowledge of marketing their products. They require the channeling of financial resources coupled with the human awakening of agents of change in the agricultural sector who can make their sustainable development effective and continuous, with a focus on financial profitability. 


\section{CONCLUSIONS AND RECOMMENDATIONS}

It is a fact that the rural sector is a pillar of economic activity. However, the place awarded in the hierarchy of macroeconomic objectives to promote its progress in Mexico has not been optimal. The rural sector represents only $3.3 \%$ of total GDP, which indicates its low productivity due to the neglect it has received from the government as well as from the private sector.

The analyzed statistical evidence shows the lag and stagnation of the rural areas of Mexico. This is considered to be a set-back in the contribution of this sector to national economic development compared to the contribution it had 33 years ago. This fact further strengthens the conclusion that the rural sector has not made progress despite all the efforts (well or poorly managed) that have been launched. There is a need to review the financial government strategies to promote the rural sector during the new presidential administration.

An increase in social welfare of those whose main source of income comes from the rural sector is urgently needed. Education is also important because they do not have the sufficient motivation and incentives to trigger agricultural production. If the possibilities of foreign trade are considered, the capacity of the rural sector to compete is at a disadvantage; its potential is not appropriately exploited to its full capabilities to be at par with the international markets and to be able to cover both domestic and external demand. The panorama of the rural sector and its future is somewhat complicated; the only option is not just to continue directing financial resources to the rural sector, but also education and guidance through programs to improve the sector with infrastructure, development and application of new technologies, and productivity programs.

Just as Reynoso proposes (2001a), the vision of a productive, profitable, job-generating Mexican rural sector, which significantly contributes to the growth of the national economy, presents obstacles of perception and approach. The rural sector, and especially small farmers, are regarded by the government and society as lagged institutions compared to modern business practices, as archaic history of the market culture that prevails today. For this reason, an improvement in the infrastructure and in the development and application of new technologies in the rural sector are essential to take this industry out of its historical stagnation.

Channeling more resources to the rural sector, just as President Felipe Calderon did, was not the proper solution to get this important sector out of its stagnation. So, what is the challenge for current President Enrique Peña Nieto? He has one research challenge - to identify the real reasons why the financial resources directed to the Mexican rural sector were not effective in providing a new life to a historically depressed sector. Directing financial resources to this crucial sector is commendable, but this effort must be accompanied by a design of educational and economic policies to support the rural sector to allocate these resources more efficiently. For example: identifying the diversity and the types of crops that have great potential, strengthening their production by increasing productivity, and giving a special priority to technological development in the sector as well as the development of its infrastructure. Financial government resources should not only be directed to pay salaries and subsidies, but through a more effective leadership, the agricultural government agencies could try to increase investment in infrastructure, development, and application of new technologies, which might allow the Mexican rural sector to be competitive at an international level, all this set in the context of civic responsibility, ethics, and a sustainable development approach where government efforts must, undoubtedly, be accompanied with an educational effort to teach people with values, to encourage them to be supportive, and to promote them to become the ideal leaders of their own communities.

\section{AUTHOR INFORMATION}

Flory Anette Dieck-Assad holds a Ph.D. in Finance from Tulane University (2003). McGraw-Hill published her first book Financial Institutions in 2004. She is an invited lecturer in Mexico, Chile, U.S.A., Canada, and Europe and got the "Best Lecture Award" in 2004, 2008, 2010, 2011, and 2012. She has more than 100 publications in national/international magazines, reviews, and journals. She received the "Prize to Education and Research" in 2007, 2010 and 2011. Texas A\&M University Press published her second book, Energy and Sustainable Development in Mexico in 2008, honored with the "National Romulo Garza Award" for "The Best Written Book." She became Tenured Professor at Tecnologico de Monterrey in 2011. E-mail: fdieck@itesm.mx 


\section{REFERENCES}

1. Ardila, S. (2006). El sector rural en Mexico: desafíos y oportunidades. Banco Interamericano de Desarrollo. Retrieved September 27, 2012 from http://www.financierarural.gob.mx/informacionsectorrural/Documents/Sector\%20Rural\%20en\%20M\%C3 \%A9xico.pdf

2. Banco de Mexico (2012). Consulta de estructura de informacion. Banco de Mexico. Retrieved September 28,2012 from http://www.banxico.org.mx/SieInternet/consultarDirectorioInternetAction.do?accion=consultarCuadro\&id Cuadro $=$ CR111\&sector $=2 \&$ locale $=$ es

3. Bosque, M. (2012). Gastan mas en agro, pero producen poco. El Norte, September 24.

4. CEPAL (Comision Economica para America Latina y el Caribe). (2011). Subregion norte de America Latina y el Caribe: Informacion del sector Agropecuario: 2000-2010, Sede Subregional en Mexico, Naciones Unidas. (Octubre Reporte 2011-060) Mexico D.F. Retrieved September 27, 2012 from http://www.eclac.org/publicaciones/xml/6/44886/2011-060-Inf.sect.agrop.2000-2010-L.1040-1.pdf

5. Dieck, F., \& Peralta, E. (2013). Energy and capital inputs: Cornerstones of productivity growth in Mexico: 1965-2004. Empirical Economics: Journal of the Institute of Advanced Studies, Vienna, Austria, 44(2), 563-590.

6. Escalante, R., Galindo, L. M., \& Catalan, H. (2005). La evolucion del Producto del Sector Agropecuario Mexicano, 1960-2002: Algunas Regularidades Empiricas. Cuadernos de Desarrollo Rural, 054, 87-112, Pontificia Universidad Javeriana, Bogota, Colombia, Universidad Autonoma del Estado de Mexico. Retrieved September 17, 2012 from http://redalyc.uaemex.mx/pdf/117/11705405.pdf

7. FIRCO (Fideicomiso de Riesgo Compartido). (2012). Quienes Somos. Firco. Retrieved September 28, 2012 from http://www.firco.gob.mx/firco/Paginas/Quienes-Somos.aspx

8. INEGI (Instituto Nacional de Estadistica y Geografia), (2011). Mexico de un vistazo. Instituto Nacional de Geografia y Estadistica. Retrieved September 26, 2012 from www.google.com.mx/url?sa=t\&rct=j\&q=\&esrc=s\&source=web\&cd=1\&cad=rja\&ved=0CCIQFjAA\&url=h $\mathrm{ttp} / / / \mathrm{www}$.inegi.org.mx/prod_serv/contenidos/espanol/bvinegi/productos/integracion/pais/mexvista/2011/m ex_2011.pdf\&ei=2gZjUP3sB6Ps2QXrzIHgCA\&usg=AFQjCNHzeofbYTzujM-vY-hK3CZ6rld3Q\&sig2=Q8Kk6HC---AbVzqIrtRY3A

9. PND (2007). Plan Nacional de Desarrollo 2007-2012 - Sector rural. (2007). Plan Nacional de Desarrollo 2007-2012 - PND. Retrieved on September 29 from http://pnd.calderon.presidencia.gob.mx/economiacompetitiva-y-generadora-de-empleos/sector-rural.html

10. Reynoso, R. (2011a). La Situacion del Campo en Mexico: Primera Parte, Fundacion Mexicana para el Desarrollo Rural, A.C., junio. Retrieved September 27, 2012 from http://www.coparmex.org.mx/contenidos/publicaciones/Entorno/2001/junio01/campo.htm

11. Reynoso, R. (2011b). La Situacion del Campo en Mexico: Segunda Parte, Fundacion Mexicana para el Desarrollo Rural, A.C., julio. Retrieved September 27, 2012 from http://www.coparmex.org.mx/contenidos/publicaciones/Entorno/2001/julio01/campo.htm 
NOTES 